inOedia $\quad \begin{aligned} & \text { InMedia } \\ & \text { The French Journal of Media Studies }\end{aligned}$

7.2. $\mid 2019$

Documentary and Entertainment

\title{
An interview with documentary filmmaker Bill Morrison.
}

David Lipson

\section{(2) OpenEdition \\ 12 Journals}

\section{Electronic version}

URL: http://journals.openedition.org/inmedia/1685

DOI: 10.4000/inmedia.1685

ISSN: 2259-4728

\section{Publisher}

Center for Research on the English-Speaking World (CREW)

\section{Printed version}

Date of publication: 15 December 2019

\section{Electronic reference}

David Lipson, "An interview with documentary filmmaker Bill Morrison.", InMedia [Online], 7.2. | 2019,

Online since 20 December 2019, connection on 26 January 2021. URL: http://

journals.openedition.org/inmedia/1685 ; DOI: https://doi.org/10.4000/inmedia.1685

This text was automatically generated on 26 January 2021.

(C) InMedia 


\title{
An interview with documentary filmmaker Bill Morrison.
}

\author{
David Lipson
}

1 Pioneering filmmakers, such as the Lumière brothers (Workers Leaving the Lumière Factory, 1895), Georges Méliès (A Trip to the Moon, 1902), or Dziga Vertov (Man with a Movie Camera, 1929) were key players in film history and the history of documentary films. They were extremely innovative trailblazers that experimented with techniques and ideas that would go on to influence future filmmakers. It was a period when the film medium was new and there were no set rules about what a film was and how it should be made. This was the silent era (1894-1929), when most films were recorded on nitrate which proved to be a dangerous and inflammable material. Indeed, $90 \%$ of these films were lost, destroyed or burned in fires because the nitrate would spontaneously combust. These lost films on certain occasions were rediscovered but retained significant decay and water damage. What some consider to be incomplete, decayed film, or at the time totally worthless material, represent today archival gold for documentary filmmaker Bill Morrison. He specializes in creating experimental collage films by reusing these lost and recovered decayed films that he recuts and reconstructs with other films and then sets them to contemporary music. He used this technique to make Decasia in 2002 (a contraction of Decay + Fantasia) by combining several films that had undergone severe emulsion deterioration. ${ }^{1}$ The film weaves an abstract and poetic narrative around these damaged silent films ${ }^{2}$ in order to contemplate the cyclical nature of human mortality and reconstruction. Decasia is the first film in the $21^{\text {st }}$ century to have been selected for preservation by the Library of Congress. ${ }^{3}$

2 His latest film Dawson City (2016) tells several stories at the same time. There is the initial story of the archeological dig in 1978 that unearthed the 372 lost silent films that were buried under a swimming pool in Dawson City in 1929. The film also recounts the history of the birth of cinema and the dangers of recording on nitrate. We learn about the history of Dawson City, a Canadian town that sprang up after the discovery of gold and then slowly died out. The filmmaker connects the content of the rediscovered film reels to the present day with constant references to current topical issues. The Silent 
Parade $^{4}$ reminds us of the Black Lives Matter ${ }^{5}$ movement and the Black Sox Scandal ${ }^{6}$ makes us think about current sporting scandals such as Deflategate ${ }^{7}$ and the film even retraces the history of how Trump's parents made their fortune. It was named the best Documentary of 2017 by the Boston Society of Film Critics, was awarded a Critics' Choice Award for Most Innovative Documentary, an International Documentary Association (IDA) Creative Recognition Award for Best Editing, as well as many other awards. ${ }^{8}$

On January $28^{\text {th }} 2018$, the Auditorium du Louvre held an exclusive screening of Dawson City immediately followed by an interview with the filmmaker. Since, I knew he would be in Paris, I took advantage of this special event to contact Bill Morrsion and request an interview. He agreed and we met the next day at his hotel where he sat down and spoke with me for one hour. My questions are organized into very distinct themes. I wanted to know how Bill Morrison came to filmmaking, how his particular career path led him to become a film artist as well as what important artistic influences infused his work. We then discussed Dawson City, its inception and construction. As this issue of InMedia explores the themes of documentary and entertainment, I asked several questions about the entertainment value in his latest documentary, his definition of documentary film, and the use of entertainment in documentary films in general. I then went back to more specific questions about his own work: What is the message he is trying to express? Is he able to make a decent living by just making documentary films? The last part is about the filmmaker's future projects and his personal definition of what a movie is.

4 I would like to take advantage of this introduction to thank Mr. Bill Morrison for agreeing to the printed version of this interview and for his help in proofreading the transcription.

5 Paris, January 29 2018, 3pm.

David Lipson: Bill Morrison, first of all I would like to thank you for taking some time out of a very busy schedule to give me a few minutes to talk about your last film Dawson City Frozen Time. From what I have read about you, you went to art school....

Bill Morrison: I went to Reed College 9 for a couple of years to make sure that I didn't want to go the traditional liberal arts college route and then halfway through my second year I still wanted to go to art school. I wanted to go to New York and I wanted to start the rest of my life.

DL: So Reed College was like a safety valve.

BM: I don't know if it was safety. My parents had a hard time understanding me wanting to go to an art school. They were worried.

DL: I see. So in this way [they figured] "he'll get a diploma in something else."

BM: Yeah this was their idea they wanted me to get a BA somewhere. I got two years into what would have been a philosophy major and realized that I was about as useful to society as a philosophy major as I was as an artist. So...

DL: (laughs). So then you went to Cooper..

BM: Yeah, then I went to Cooper Union. 


\section{DL: So what led to that choice? Why there?}

BM: It was an all scholarship tuition-free school and so it avoided this whole conversation about asking to go because you didn't need to pay anything. It became more a question of self-determination.

DL: It was all expenses paid.

BM: Once I got in, then I could say this is what I am doing.

$\mathrm{DL}$ : And your parents were ok with that?

BM: They were, and in fact it led to an improvement in my relationship with my father because he in particular was very wary of this idea of me becoming an artist.

DL: Now your mother is a teacher and your father is a ...

BM: He is a lawyer-he was a lawyer, he passed away. At that time, I wrote him a letter describing my choices and also comparing some of his choices to mine. It was a marked improvement in our relationship ever after. We were very good friends after that.

DL: I want to stay on this area about art and influence. I'm surprised, now maybe I haven't read all the interviews that people have done with you-but one of the artists that I think about when I look at your work is Francis Bacon. Did he have an influence on you is or was it just by chance?

BM: I love his paintings. You mean the decay and the opulence? That's a great comparison. I hadn't thought of that as being a direct influence, though I certainly see what you mean.

DL: Maybe unconsciously...?

BM: Maybe unconsciously. I mean I'm attracted to the same theories but I never thought about making a film in the style of Francis Bacon.

DL: Now another artist, maybe not as obvious, is Rauschenberg.

BM: Do you mean the collage? Yeah, I saw his retrospective at MOMA ${ }^{10}$ this past summer and I wasn't aware of just how far reaching all the different media is. It's quite remarkable.

DL: Now I mention Rauschenberg because De Antonio cites him as a huge influence in his work.

BM: Oh really, well they were contemporaries too.

DL: They were friends and he had this idea of making the film by taking the pieces and putting them together,

BM: You know Joseph Cornell ${ }^{11}$ was more of a direct influence. Of course, he was a filmmaker.

DL: Okay. All right. I have some other questions about that but I want to move on because I'm worried we won't have enough time...

BM: Yeah, yeah, I would just also say Max Ernst.

DL: OK, good, surrealism,...

BM: And collage.

DL: Ok let's talk about Dawson City. Why do you think nobody had made this film before you did? The remnants were discovered in $1979 \ldots$

BM: 78 
DL: Yes, you're right in 78. And you said last night "Thank God nobody had discovered it"12. Is it because the technique hadn't caught on? Were you just lucky?

BM: I have many theories about it, of course, and this isn't anything I can answer definitively. The choice to make a film or not make a film -- I think that when the collection was discovered there was a lot of excitement about the circumstances under which this was found and in some ways this had eclipsed what the contents of the actual discovery were. And it almost was enough for people to say that there were films found in a swimming pool and not discuss which films were found. I think that from a traditional archivist standpoint it was a frustrating find. Because there were little remnants, a reel here, a portion of a reel there, but there was no entire feature intact, there was no great discovery that was going to contribute to cinema history. And that's what...

DL: And that's what people were looking for.

BM: ...that's what people were looking for, whereas I'm looking at much more of a buffet table of images and disassociated scenes. So, in a certain way it was made to order for me. The other thing is that as a story it had gotten retold incorrectly many times, even positioning it in Alaska as opposed to Canada.

DL: You mentioned [during your speech last night] that it went off the rails.

BM: Yeah, I was even at the Library of Congress, which is one of the big collaborators with the restoration, and CNN happened to be there doing an interview and one of the archivists said "Oh yeah there was this bowling alley in Alaska."

DL: [laughing] "[They might as well have said] It's on the other side of Russia..."

BM: Yeah, and if that's what they're saying at the Library of Congress, then what are they saying elsewhere? It gave me this sense that human memory is not only fragile but it only has a shelf life of about eight to ten years and then people start forgetting things. So I think this story had been sort of put safely to bed. I'm not sure why there wasn't more written about it. Certainly Sam Kula ${ }^{13}$ wrote two articles but they're basically identical articles for different publications. And they don't say that much. They talk about his experience of going there and finding them. Then they talk about the most well-known stars, the people whose names have really survived, who were in the collection. If you go to the library and archives in Canada there is a data base but that's not publicly available. There's also an internal memo that was chock full of errors. You know, just absolutely complete -- even from page one to page seven there's errors and inconsistencies. It's a mystery to me why even just in a scholarly way it wasn't written about. In some ways it's curious that no one made a film just because there was a lot of film material there. But I say thank God because of course this became a thing. After Decasia ${ }^{14}$ it's the film that I will be best remembered for.

DL: Well, as you know you never know what the future holds and you kind of look back afterwards and [then] you can say it. But at the moment you are kind of waiting to see what material--

BM: And I do know and I knew this all along that this was a singular story. And that I was going to tell it in a singular way. I have compared it to Titanic, because there are only a few stories that embody the $20^{\text {th }}$ century in such a perfect way. From my standpoint, there's some of the same mythical qualities that a true story like Titanic has. 
DL: My reading of it when I saw it last night, was that you were trying to build a narrative around it and exploring all the different aspects that can be used trying to attach it to the present: the reference to Donald Trump, to other things that are going on today. So I think that's to your credit as a filmmaker. You didn't just [merely say to your audience] "OK here's some archival footage." Now, it wasn't clear to me from your answer last night, did you say that you watched all three hundred and twenty-two films?

BM: [correcting] So, there are three hundred and seventy-two titles,

DL: Three hundred and seventy-two, yeah ${ }^{15}$

BM: I haven't seen all of them.

DL: How many did you see?

BM: I've seen all the newsreels. In the silent films, I really just picked through until I could tell my story and find ways with the resources and the time I had. I saw quite a bit and I think I've seen more than just about anyone else. But at one point the important part was the newsreels. And they had a position within my film and then the rest was almost illustrative and poetic. And then there was quite a bit of supporting material that was almost equally as important.

DL: So I get a sense that you had this idea of the story you were trying to build and then, as you were filling it in, at one point you came to a moment where you felt "OK I have enough, I don't need to dig anymore."

BM: Yes, that's absolutely true. I understood that once I took this rather small incident-these films being buried in the swimming pool-and then, it becomes somewhat mythological or metaphorical once they sat underground for 50 years. Miraculously the Gates ${ }^{16}$ took pictures of the exhumation. So that got me to that side of the century. And then going back, I found it really compelling that the original year that cinema was shown publicly coincided with the same year that gold was found in Dawson City [which]was going to be the other end of that. So I did see it as a time line connecting 1895 or 1896 to 1978. And it so happened that there was quite a bit of material not just within the project but there was Edison and there was the Dawson City film find and then the home movies and other archival material that would support it. And, as I started looking through the Dawson City film find material itself, a lot of these themes of labor, and there's also a reference to the African American protest parade and the sexual harassment. There are a lot of things where you can see the fear and misogyny that are pervasive in our culture now in its nascent stages.

DL: Yeah, there is a circular aspect to it, the more things change the more they stay the same. We are dealing with these same problems today.

BM: Well, we certainly haven't solved them, that's for sure.

DL: Now linked to this aspect of your digging, was there a particular length or it could have been any length? You weren't saying for example "It has to be two hours, or ninety minutes."

BM: A lot of people were interested in me exploring the idea that it be shorter. [both laugh] I was getting a suggestion that I should try to trim it down but that would have involved -- If there was any part that would get excised -- it would have been that whole newsreel sequence, a lot of the labor, which I thought was really important but that was the part that could have been neatly snipped out of it. And, yes, it would have made it ten to fifteen minutes shorter. 
DL: You didn't have a clear idea? For you it was "I just want to tell the story and if it takes me two hours then I'll take two hours."

BM: Yeah, I've wrestled with that. My producer was very clear that she didn't want to sell this if it was over two hours.

DL: So that was seen as a maximum limit?

BM: Yeah, and in terms of whether to include the newsreel stuff, that was the stuff I found to be really amazing. Alexander Berkman ${ }^{17}$, The Ludlow Massacre ${ }^{18}$, The Silent Parade, those were all remarkable things, The Black Sox, -- it wasn't as miraculous a discovery without them. Otherwise it was a collection of movie stars that are overacting and people that we have barely heard of. Yeah. So I thought the real gold was in the newsreels.

DL: I have a question about the music. It's a question but also an opinion. When I compare the music in Decasia --and I have to be honest I haven't watched all of Decasia just parts on YouTube-- I find it to be an integral part [of the film]. There's a harmony between the image and music. Whereas for this film Dawson, I find it to be not so harmonious, almost, at times, a competition; where sometimes the images are supported by music or it's music being supported by images where the music becomes almost oppressive. That was my experience. What is your take on it?

BM: Well, I think with all my other projects I had the, in some ways, the luxury of editing to the music. And in this case I'm working in a more traditional sense where the soundtrack scorer is scoring my images. I'm not recutting to the music. In some ways I had more control because my edit was my edit. But in some ways, he was also choosing some of the breaks, which were different than my breaks. And so where a cue began and ended where I didn't have a cue. That was different but then I came to see his point of view. He did have a clear point of view why he wanted something to start there so it was collaborative in nature. The thing about Dawson City that's different than Decasia or any other film that I have made is that there is just an enormous amount of information that I am trying to communicate. It's asking you to read and process as well as listen to loud music. So if there is a competition there, it's not just the type of music it's the challenge I've set for the viewer.

DL: Maybe the density?

BM: Yeah, the density.

DL: I spoke with your mother and sister [sitting next to me in the audience] and they said that they had seen it a number of times and I asked them about that experience and they said: "Each time we see it again there's always something new." There is that possibility that you see it once and then the second time you are bored.

BM: Sarah has seen it three times but I think my mom has seen it seven times-but then again she's my mom-[both laugh] but they said that it took that long for them to be relaxed, it took three times for them to understand all the detours the film makes, to understand that it would come back and not be nervous and say "why am I being taken through this period which I might be remembering?" It was a kind of faith that everything is going to resolve and it was going to have meaning. For first time viewers they might say "they're throwing too much stuff at me."

DL: It's interesting [because] that wasn't my feeling. Of course, maybe I am not in the same mode [as them]. I am thinking actively about what's going on [from the stand point of a film critic rather than just a viewer]. What I noted was also that there was entertainment value 
[in the film], not that it was trying to be entertaining. What I mean by that is that the sequences are very short, there are juxtapositions. I didn't feel bored.

BM: Oh good [laughs]

DL: But seriously, I've seen films that can be two hours and that can be boring. And it was late at night ${ }^{19}$..

BM: I'm glad, because at one point I hadn't shown this film to anybody, I wasn't convinced-because I also didn't know of any other film that was like this where it was told in text and with quite a bit of information and images and this music-I didn't know if I wasn't making the most boring film [laughs] in the world.

DL: Well, I have a question about that later. So, next question, at the very beginning of the film, and I am not sure if this was a conscious decision but there's a little short extract of you appearing on a radio show or something. And then afterwards we cut to the film. What was that about? You wanted to make a little Alfred Hitchcock cameo, or you wanted to start with you?

BM: Well, first of all, that clip does several things. It firstly says this is a story that's being told from the vantage point of 2014, not 1978 or 1979. Forty years have passed since the discovery [of the film footage]. And it hasn't been told since then. It was almost the first time this story has been told. It's been in the archive almost as long as it's been in the ground. So, its first stake in the ground is to say this is 2014 and I haven't even made the film yet at that point. I'm just researching it and I found the Black Sox footage and that's permeating out into the baseball world. And it also setsI come out of an avant-garde tradition and also a tradition of using found footage in a world where found footage is sometimes used to tell a fantastical story, a story that's not true. And it was very important that people understood that this is a true story. This could be on a news program, on a baseball program where they are very in tune with facts and scores and dates.

DL: PBS?

BM: Yeah. And that you're being told this true story and you're being told this true story by Bill Morrison. So that's what the setup is. And it's also how I answered the question last night that I saw this as an archaeological dig and the research was an archaeological dig. And this was the most surface and banal imagery in a way that you could find, the type of imagery you could find in a bar, any sports bar where two guys are sitting at a sports desk talking baseball. And from there I would dip back to imagery from 1978 or 1979 and then on down to the beginning of nitrate in the Lumières ${ }^{20}$ and then climbing up through the history of moving images.

DL: OK, well I guess I asked that question because I was thinking of the whole debate about the documentary filmmaker putting themselves into their own movie. But this was very discreet.

BM: And I happened to say, when I was asked to do that interview, it never occurred to me that it would be in the film. I'd say well "it was an incredible story" and that's a great point to begin the story. There was that, and it was a good thing to have said. And then the Black Sox footage was in some ways the story that got the most media attention. You know those five minutes of the 1919 World Series that nobody knew existed and in fact included, incredibly, the failed double-play that was in the testimony.

You know when you slow down that play, you think of all the possible things that made it possible for that play to be seen today. First of all, there had to be a 
cameraman filming that play and then it had to make the edit of that newsreel and then it had to go out on tour and be sent to Dawson City and then it had to make it into the library rather than into the river to be burned. It just so happened, it was in the swimming pool and then it had to be one of the films that was pulled out of the swimming pool and deemed to be restored and then sat for 40 years before I came along and said "This is the 1919 World Series." So even though it had been labeled as a 1919 World Series nobody up there had seen the significance of the fact that they had footage of that. So, in some ways that footage best embodies the incredible chance, the element of chance that any of this survived.

DL: I think it goes back to what you said earlier, that you were the first one to make a film out of this because it just happened to suit your needs and nobody else saw the treasure that you had seen in this. And maybe this is the interesting part which is that maybe "treasure" is not necessarily something absolute but it's what we do, it's what we find.

BM: Well, I made Decasia, right, a film that finds treasure in how distorted these images are. To many archivists, it was a great source of frustration that these images had what is called "the Dawson flutter" which isn't even nitrate damage, it's water damage because of the way they were handled when they were taken out of the swimming pool in 1978. It's almost a tragedy, for most archivists to look at the condition of these. I know in the Library of Congress the nitrate vault manager would like to get rid of the entire collection, and I said "you can't. It's already sat in Dawson for 50 years, you can't throw it out." But he would like to make room for other stuff that is in pristine condition. For me I was attracted to the collection because it had this flutter to it. It was better suited for me to find that beauty than someone else.

DL: Now, you mention the fact that you always get asked this question "Did you have a special app to produce these weird effects?" I was just thinking about how you looked through the films, and of course you chose [scenes because you felt] "Oh, I like this effect that was created by the water".

BM: They call it the "Dawson flutter".

DL: The Dawson flutter, yeah. Have you thought about taking a nitrate film that was in pristine condition, and putting it in the water to create an effect?

BM: I wouldn't do that to a nitrate film that was in pristine condition.

DL: Is there a way of reproducing a nitrate film? Maybe it's too dangerous.

BM: I see, if I was to take a safety...

DL: If you copied one...

BM: I could do that. I've buried films. I've put Drano ${ }^{21}$ on films. I'm more interested in how something actually came -- the historiography of a real film, how it came to look...

DL: --not you participating actively..

BM: Yeah, I used to do that. That's more of an avant-garde trick.

DL: OK. I'm going to move on to the third part of these questions, which are more general and closer to the subject of documentary and entertainment. My first question is a philosophical one. How would you define documentary film? For this catch-all category, what would be your definition of documentary film?

BM: Well, for me, it's using film as the document. And that's why I think it's a wonderful description of what I do. I'm actually looking at these clips of films for 
their materiality as well as their content. The film is a documentary film. But that's very specific to my needs.

DL: If you were talking to somebody on the street, and you were trying to explain to them "this is documentary film" and "this is not documentary film," how would you draw the distinction?

BM: It's hard to say. It's easier to say what is fiction and non-fiction, because I think there are documentary films that incorporate fiction in an interesting way or the perception of truth, right. A good documentary film isn't constantly in dialog with "Is this the truth?" or...

DL: A good documentary film will not make the viewer or the critic suspicious of the overall truth..

BM: Or it'll make its intentions clearer. I think there are brilliant films that are in some ways allowing the viewer to question whether this is in fact true or not. But maybe in an effort of getting at another truth or telling a more interesting story. But they're not trying to pull the wool over your eyes necessarily either.

$\mathrm{DL}$ : They are being clear from the beginning.

BM: Yes, it's the intents, they are saying this is the story. That's important. But I think a documentary film is a good catch-all [category] and I think the notion of truth is elusive at best. It's always going to be someone's point of view and there's going to be some people who will say that my film is strictly a product of my point of view and the research and the history. And the indigenous people would have a completely different perspective on what happened and what was important about it.

DL: Nobody would ever see your film and say it's not a documentary.

BM: No. I don't think so. That was another point that I liked about that introductory clip and the baseball interview, was that he said "here's Bill Morrison and he's a documentarian. He put this all together." I have recast myself as a documentarian here rather than an avant-garde filmmaker or somebody making experimental films.

DL: So, I want to stay on the subject of subjectivity/objectivity, what is a documentary, what is not a documentary. So, I assume you would agree with what Wiseman said when he said that this debate about subjectivity and objectivity is just a bunch of bullshit. A documentary film is always subjective. There is no objectivity. ${ }^{22}$ So you would agree with that?

BM: Well, first of all, everything is dependent on who's holding the camera. And then it's dependent on the day that person is holding the camera. And what happens to intercept their camera. There are some things that you can control. The best parts of a documentary are things that you can't control. I don't think there is any objective truth, once you have a camera running and people are aware that there is a camera there, then, that already changes the dynamic in a room. So, yeah, I would agree with that. And I think Wiseman is our best living documentarian.

DL: I thought the quote was interesting because he's revered as this kind of objective documentary filmmaker. And he's saying, "No, I don't want to be put in this category."

BM: Also, his edits are very much a point of view. They are essays.

DL: Now, what do you think about the current trend of a lot of filmmakers trying to incorporate entertainment into the documentary film, and the subjectivity...

BM: Give me an example. 
DL: Well, Michael Moore ${ }^{\mathbf{2 3}}$, Morgan Spurlock ${ }^{\mathbf{2 4}}$, Al Gore ${ }^{\mathbf{2 5}}$, these films that are trying to combine the documentary objective aspect of discourse with narrative and entertainment processes in order to get a large amount of people to go and see the film.

BM: Well, that's a different approach. I met Brett Morgen ${ }^{26}$ a few weeks ago and he said "The way I choose a subject or a topic of a documentary is: I think "what are a lot of people going to see at the theatre?" That's the first question he asks. He's not going to explore something that is not going to be successful at the box office. And that's an approach. Therefore, he's positioned himself in the industry as somebody who's going to make blockbuster documentaries. So I think that has led him to projects like The Rolling Stones ${ }^{27}$, Kurt Cobain ${ }^{28}$ even Jane Goodall. ${ }^{29}$ But he does it in very artful and compelling ways. A lesser filmmaker could take the same topic and not make as good a film.

DL: So, you still need to be talented.

BM: Yeah, you have to be obsessed with your topic, I think.

DL: So, I want to continue with this line of questioning. Getting to yourself, I am going to give you a quote by Emile de Antonio and by Michael Moore and [I want you to tell me] which one you feel you are closer to. Emile De Antonio said "I make boring political films." ${ }^{\mathbf{3 0}}$ And Michael Moore says "I make a film that people want to see on a Friday night."31 So are you Emile De Antonio or Michael Moore? Or are you something else?

BM: I am Bill Morrison.

DL: So, Bill Morrison says what about his films?

BM: Well...

DL: It's a film to do what?

BM: I make different types of films but I think they engage with the medium of film. Therefore, they are self-reflexive about the art, they are self-reflexive about the passage of time and in a way that the audience is forced to interrogate about that as well. It becomes some sort of a meditation that you have to participate in or you are going to resist and leave or turn it off. The degree to which you are open to that is the degree to which the film is going to be successful for you. But, I would never say I make films for this or I make films for that; I make films for me. The people who want to engage in it are going to have an idea going in; they have heard something about it. Michael Moore did revolutionize documentary film as mainstream entertainment, and not only that mainstream entertainment with a solidly leftist hook to it, and he needs to be applauded for that. He made himself into a character, almost a cartoon character fighting on behalf of the worker. Emile De Antonio is completely different, he's engaged with the medium in a different way. These are films that would be shown in museums. They will always be part of the history of cinema-not that Moore hasn't carved out his own niche in history. Firstly, I don't think about my audience in that same way. I don't think I am making a film for this person or that person, or for it to be shown in this context or that context. Dawson City was a film I felt I had to make. I thought it was a film that I could make in a different way than anyone else. I came to realize that it was a story that people had forgotten, and that it would be understood as a new story. And that it had a chance to be shown a lot more than any more of my other work. And that was true. Kino Lorber ${ }^{32}$ did a very good job with it and got it out to a lot of theaters in North America. Certainly not as many theaters as Michael Moore, or probably even Emile De Antonio 
DL: Well, it depends. Some of Emile De Antonio's work has a lot of viewers for it, but some of his work is very obscure. Nobody, I think, knows about the film Painters Painting. ${ }^{\mathbf{3}} \mathrm{Ok}$, so I want to continue then [with this line of questioning.] Would you rather-there is no right answer-win an Oscar or make a blockbuster documentary film? Or in-between?

BM: I would prefer that this one (Dawson City) had won an Oscar but it didn't get nominated. [DL laughs]. A blockbuster documentary film almost would mean that it would be about something I was not particularly interested in. What would be a blockbuster [documentary film]?

DL: It's a question about the number of people seeing the movie versus recognition, critical acclaim versus profit and getting lots of people to see the movie.

BM: Critical acclaim, I think, Dawson City has got. It has won a couple of awards. It made 100 best of 2017 .

DL: Yeah, I saw that on Facebook.

BM: Yeah, a lot of stuff. Critical acclaim it got. The funny thing about the Oscars and the documentary, it's an older part of the academy. A lot of these people vote without having seen everything. There's a history of the greatest documentary films-Michael Moore being one of them, Errol Morris ${ }^{34}$, Steve James ${ }^{35}$-- where real landmarks of documentary history in the whole last 30 years of documentary film haven't been nominated let alone not won anything.

DL: Michael Moore won an Oscar for Bowling For Columbine.

BM: But that was many years after Roger \& Me, Errol Morris won for The Fog of War many years after The Thin Blue Line. Steve James is nominated this year for Abacus many years after Hoop Dreams. None of these films were nominated, they are landmark films. The academy's relationship to critical acceptance, it's ...

DL: It's all relative.

BM: ...relative, I would never give 20 Feet from Stardom ${ }^{36}$ a documentary film award. I'm sorry, but this is my opinion. I didn't think it was the best film. There was this incredible film called The Act of Killing ${ }^{37}$, it was that year, absolutely astounding film. On the other hand, making a lot of money off my films is not that important to me. My films cost money, they don't make money.

DL: Are you able to live off your work?

BM: Yeah, I do work on consignment a lot and commission. That gives me some work. I would say that to make a blockbuster documentary film, it would have to be a very compelling film. It would have to be in some ways uncovering a truth that everyone needed to see on film. In some ways, Icarus ${ }^{38}$ did that this year with the discovery in the Russian doping scandal. The Thin Blue Line discovered that a [convicted] man was actually innocent. A blockbuster documentary film would be not just for its monetary return but it means that there is something in the film that was actually affecting a lot of people and made it a must see.

DL: Well, I think you have the content, meaning something in the film is important, it will affect a lot of people; but afterwards you have the marketing. There has to be some kind of machine behind it.

BM: Behind it, yeah. I think a lot of these films, some of them, benefit from that. At the same time, we were just talking about Brett Morgen: Jane ${ }^{39}$ won an enormous number of awards, it was short-listed but it wasn't nominated this year. It had National Geographic money behind it. It had the cover of Variety this month. So there wasn't a lack of exposure. So, the academy is fickle and the public, for them to go and 
buy tickets, especially in this day and age in a theater instead of getting a Netflix or Amazon deal. It means that you have made something pretty compelling. So to answer your question, I would take the blockbuster.

DL: Ok, last question then: what is the future for you? Future prospects? You mentioned Netflix, have you thought about maybe going towards this media that young people would be more...

BM: more inclined to see. I think those doors are starting to open up to me more in the wake of this film. I think I was regarded as some sort of relic...

DL: [laughs] to be buried under a swimming pool

BM: Yeah. But, I think this film showed that there is interest in this kind of approach to history and these strange films. In the same way that vinyl became an interest for people. That's something real, something physical. So, that's an interesting conversation, in the last week I have talked to Nat GEO ${ }^{40}$, have talked to $\mathrm{TCM}^{41}$. Who knows, I still have a lot of ideas. Dawson was an idea I had in my sock drawer for twenty years. There are others.

DL: What about fiction?

BM: Well, the thing about it is that I always say "Yes, I'd like to do something in fiction but then I never do." People keep asking me "When are you going to make a real movie?" But, I never do it.

DL: [laughs] These are fake movies.

BM: Yeah, they are not real movies, right? There are certain types of scripts that I find very compelling. I found Robert Altman's The Player ${ }^{42}$ very compelling because there was a telling of that story, the manifestation of the script that you've just read or you've just watched. So, that's what drew me to Dawson. Here was this story of the film.

DL: Well, you can think about a series. Have you seen Deadwood? ${ }^{43}$

BM: Yeah, I've seen parts of it.

DL: This could be like a TV series. Well anyway, I'm just throwing out ideas...

BM: There's a lot more left in the Dawson Collection to tell you the truth. And there are other stories that I am interested in too.

DL: Well, this is more of an open question in terms of "What are your future projects, what could that possibly be?"

BM: Well, there is one story I have been working on for the last year. In 2016 these films were found in the bottom of the ocean by a lobster trawl. They trawled the bottom of the ocean and up came four films. They only happened to be fifty years old. They were from 1968. They were Russian films. So no Westerner has ever heard of this actor, Mikhail Zharov. But he actually had 70 titles. So I've been hitting the archive in Toulouse, in Bologna, in Moscow for his titles. To use this as a resource to tell his story, which ends up at the bottom of the ocean.

DL: It sounds like you are really into this [subject of] serendipity and lost treasure, one of your interviews [referred to you as] "Bill Morrison: the film archeologist". 44

BM: Yeah, what are movies? They recreate a subjective experience of sight and sound. So, when we are in the theater they are experiences or stories that we share. And then when they are all reeled up and put back into a can, they are physical representations of those experiences and memories. They are for better or worse, 
they are the best we have come to a model of a memory, so that what happens to them when they are stored, thrown away or how they are able to be shared, how they are able to be transported through time is a compelling story. It is immediately a compelling story. It says: "How do we survive? How do our stories survive? How does the human experience go through time?"

DL: Right. "What am I going to leave behind?"

BM: Yeah. "What have I already forgotten? What if I could never know?" With this Russian actor what I think is intriguing is the Fedex guy comes to my door, he has a Russian accent and I ask him "Have you ever heard of Mikhail Zharov?" He says [imitating Russian accent] "Oh, Mikhail Zharov, everybody knows him". But absolutely nobody knows him, no archivists, no film historians in the West. You have to absolutely be a Soviet film scholar to have heard of this guy.

DL: This could be an opening of a new market. You have to go to Russia to market this film, you need Russian subtitles..

BM: There is absolutely no question in my mind that somewhere in Siberia there is another Dawson City, because it was at the end of a distribution line, there was no way that it got shipped back. It must have gotten buried. There has to be a cache of films there. There has to be one in Chile or Cambodia. Anywhere the West came, anywhere the film industry came.

DL: Thank you very much [for this interview].

BM: Hey man, it was great talking to you. Thank you for chasing me down and insisting we do this.

\section{ENDNOTES}

1. Takeone Cinema, Interview with Bill Morrison, http://takeonecinema.net/2018/interviewwith-bill-morrison/ < accessed on August 28th $2019>$.

2. Among the many films, two have been clearly identified: J. Farrell MacDonald's The Last Egyptian, 1914 and William S. Hart's Truthful Tulliver, 1916

3. Washington Post, https://www.washingtonpost.com/entertainment/movies/library-ofcongress-announces-2013-national-film-registry-selections/2013/12/17/eba98bce-6737-11e3ae56-22de072140a2_story.html < accessed on August 28th 2019 >.

4. The Negro Silent Parade was a silent march protesting violence against African-Americans in 1917.

5. Black Lives Matter is an activist movement that was founded in the summer of 2013 to fight against systemic racism experienced by African Americans.

6. The Black Sox betting scandal occurred when several players of the Chicago White Sox, a heavy favorite to win, accepted money in order to lose the World Series in 1919.

7. The New England Patriot's quarterback Tom Brady was accused of using footballs that were inflated below the level stipulated by the rule book during the AFC championship game in 2015. Jason B. Hirschhorn, "Patriots lose 2016 1st-round pick, fined \$1 million for DeflateGate role https://www.sbnation.com/nfl/ 
2015/5/11/8561821/patriots-punished-nfl-deflategate-draft-picks-fined < accessed on August 28th $2019>$.

8. Dawson City Frozen Time awards, IMDB https://www.imdb.com/title/tt5215486/awards? ref_-tt_awd < accessed on August 28th 2019 >. More information on Bill Morrison's biography and awards can be found at the following website: http://billmorrisonfilm.com/bio-filmography? fbclid=IwAR0rv1DrujAnOqd-_0NuQVbn9K_RxTgQ3zVHxPUoYbj-6HAx2G8Hij5Td5I .

9. Reed College, located in Portland Oregon, USA and founded in 1908, is a private liberal arts college.

10. Museum Of Modern Art in New York.

11. Joseph Cornell was an assemblage artist and experimental filmmaker.

12. $Q$ \& A with Bill Morrison about the process of making Dawson City and his intentions

13. Sam Kula is President of the Association of Moving Image Archivists, a Special Advisor to the Canadian Cultural Property Export Review Board and the author of several books on film archives such as The Archival Appraisal of Moving Images: A Ramp Study with Guidelines, Paris, UNESCO 1983 as well as Appraising Moving Images: Assessing the Archival and Monetary Value of Film and Video Records, Lanham Maryland, Scare Crow Press, 2002.

14. Decasia (Bill Morrison, 2000) is a collage film that showcases old decaying silent films but also by extension a reflection on the passage of time and human mortality.

15. An extensive list of the films that appear in Dawson City can be found on the IMDB https:// www.imdb.com/title/tt5215486/movieconnections?ref_=tttrv_ql_6 < accessed on July 25th 2019

16. Michael Gates was the curator of Collections at Parks Canada from 1977 to 1996 and wife Kathy-Jones Gates served as Director of the Dawson Museum from 1974 to 1986. They both undertook the process of digging up the films and getting them to the National Archives in Canada.

17. Berkman was a famous anarchist writer and the partner of Emma Goldman.

18. In 1914, 21 men, women and children were killed when the Colorado national guards attacked and set fire to a tent colony of 1200 striking miners in Ludlow, Colorado.

19. The screening at the Auditorium du Louvre started at 8:40 pm.

20. The Lumière brothers (Auguste and Louis Lumière) were among the first filmmakers whose improved version of the cinematograph allowed for simultaneous viewing of films by multiple parties. Among their ground breaking films, Workers Leaving The Lumière Factory in Lyon, 1895 is considered to be one of the first motion pictures ever made.

21. Drano is the name of a brand of drain clog remover used to clean blocked sinks and pipes. It contains very corrosive ingredients like sodium hydroxide commonly referred to as caustic soda.

22. Wiseman expressed this in his interview with G. Roy Levin. G. Roy Levin. Documentary Explorations: 15 Interviews with Film-makers. Garden City, N.Y. : Anchor/Doubleday, 1971, p. 321.

23. Bowling For Columbine (Michael Moore, 2002) and Fahrenheit 9/11 (Moore, 2004) as well as the aforementioned Roger \& Me (Moore, 1989) are good examples of this.

24. Super Size Me (Morgan Spurlock, 2004).

25. An Inconvenient Truth (Davis Guggenheim, 2006).

26. Brett Morgen is an American documentary filmmaker, whose films have won critical acclaim. His film On the Ropes, 1999 was nominated for the Oscar of Best documentary feature, it won the International Documentary Association Award for Best Documentary Feature and the Sundance Film Festival Special Jury Prize for Documentary.

27. Crossfire Hurricane (Brett Morgen, 2012).

28. Kurt Cobain: Montage of Heck (Brett Morgen, 2015).

29. Jane (Brett Morgen, 2017). 
30. Randolph Lewis, Emile de Antonio: radical filmmaker in Cold War America (Madison, Wisconsin: The University of Wisconsin Press, 2000), p.21.

31. Michael Moore, cited by Paul Fischer, «The 2002 Toronto Film Fest, Day three » Film Monthly (2002). http://www.filmmonthly.com/Behind/Articles/Toronto2002/Toronto2002.html < accessed on June 22, $2013>$.

32. Kino Lorber is the film distributor.

33. Painters Painting (De Antonio, 1972).

34. Errol Morris's 1988 documentary The Thin Blue Line is considered to be one of the best and most influential documentaries ever made. He later won an Oscar for his 2003 documentary The Fog of War.

35. Steve James is a film producer and American documentary filmmaker who made the ground breaking documentary film Hoop Dreams in 1994, the only documentary film to be nominated for an Oscar for best editing. His latest film Abacus: Small Enough to Jail was nominated for the Oscar for best documentary in 2018.

36. 20 Feet from Stardom, (Morgan Neville 2013) won the Oscar for best documentary in 2014.

37. The Act of Killing (Joshua Oppenheimer, 2012) tells the story of the people who committed the mass murders in Indonesia from 1965-1966.

38. Icarus Films is an American distribution company for documentary films.

39. Jane (Brett Morgen, 2017) is a biopic documentary about renowned primatologist Jane Goodall.

40. National Geographic.

41. Turner Classic Movies a U.S. Television channel.

42. The Player (Robert Altman, 1992).

43. Deadwood (David Milch, Home Box Office, 2004-2006) is an American western TV series.

44. The Louisiana Channel, "Bill Morrison Interview: The Film Archeologist", https:// channel.louisiana.dk/video/bill-morrison-film-archaeologist < accessed on August 28th 2019 >. 